\title{
Indonesian Students' Writing Proficiency and Their Ability in Using Complex Sentences
}

\author{
${ }^{1}$ Bambang Yudi Cahyono, ${ }^{2}$ Nur Mukminatien, ${ }^{3}$ Rosyi Amrina \\ ${ }^{1,2}$ Universitas Negeri Malang, Indonesia, ${ }^{3}$ Universitas Lambung Mangkurat, Indonesia
}

\begin{abstract}
This study investigated EFL students' proficiency in writing, their ability in using complex sentences, and how these two variables are related. It involved 54 students who attended Argumentative Writing course at the English Department of Universitas Negeri Malang, one of the prominent universities in Indonesia. The students were asked to write an opinion essay on general issues. The essays were analyzed to measure the students' proficiency in writing and to identify the number of sentences, and the number of complex sentences, as well as the proportion of the use of complex sentences compared to the use of other types of sentences. Pearson product moment correlation was employed to examine the correlation between the number of sentences, the number of complex sentences, as well as the correlation between the students' proficiency in writing and the number of complex sentences they produce. The results revealed that the students' proficiency in writing was fairly good (at intermediate level) and the use of complex sentences outnumbered the use of other types of sentences. There was a significant correlation between the number of sentences and the number of complex sentences as well as the correlation between the students' proficiency in writing and the number of complex sentences they use.
\end{abstract}

Keywords: writing proficiency, complex sentences

\section{INTRODUCTION}

English is an international language, and one of the foreign languages that many students need to learn. One of the English language skills they need to master is writing due to its importance in academic written communication; and yet, this language skill is difficult to learn. One of the reasons that make writing difficult for Indonesian students is the fact that it requires the mastery of various components, namely content, organization, language use, vocabulary, and mechanics (Hartfiel, Jacobs, Zinkgraft et al., 1985; Jacobs, Zinkgraft, Wormuth, et al., 1981; Oshima \& Hogue, 2006, 2007; Smalley, Ruetten \& Kozyrev, 2001; Zemach \& Rumisek, 2005). Experts in writing believe that the five components of writing have different degrees of contribution. For example, Hartfiel et al. (1985) determined that content makes up the highest weighting (30\%), followed by language use (25\%), organization $(20 \%)$, vocabulary $(20 \%)$, and mechanics $(5 \%)$. According to them, this is because the most important purpose of writing is conveying ideas to the readers; in other words, content is the primary focus although it does not mean that the other aspects are not important. Thus, in order to be proficient in writing, EFL students need to have good knowledge of the topics, write the topics by using accurate grammatical rules, organize their ideas coherently, use various and relevant dictions, and be aware of mechanical aspects such as punctuations, spelling, capitalization, and paragraphing.

Given that EFL students need to have overall proficiency in writing, the teaching of all components of writing is necessary to boost their writing proficiency. However, handling the students' difficulties in the five components of proficiency in writing is not an easy task for English teachers. It is believed grammar is an important tool to convey meaning (content); therefore, grammatical accuracy is crucial, otherwise, meaning is obscure, or the intended message is not effectively conveyed. Considering its important role, this study intended to examine the students' writing proficiency including their ability in using language, especially using complex sentences, as part of language use component out of the five components of overall proficiency in writing,.

The rationale of focusing on language use is that grammar is the frame through which meaning is expressed. In reference to Second Language Acquisition (SLA) theories, it has been believed that maturity in writing is shown by the learners' ability to produce complex sentences (Dulay, Burt, \& Krashen, 1982; Krashen, 1981; Krashen \& Terrel, 1983). It suggests that grammatical competence is 
crucial in written communication. The facts show that beginners usually write short simple sentences as they haven't had the competence to produce more effective sentences and they haven't acquire the ability to combine ideas into complex sentences. Canale and Swain (1980) and Savignon (1983) place grammatical competence (the learners' knowledge of language rules) as the first component in Communicative Competence model in language teaching. Then it is followed by sociolinguistic competence (the social rules of language use), discourse competence (the ability to connect sentences/utterances to form a meaningful whole, and strategic competence (a strategy to compensate breakdowns in communication) as the last component.

SLA theories posit that L2 learners internalize grammatical rules in two possible ways: through acquisition and learning. Acquisition happens in untutored settings from natural language use where L2 learners are exposed to comprehensible input (Krashen, 1981, 1985; Krashen \& Terrel, 1983), while learning takes place in the forms of form-focused instructions by giving learners acquisitioncompatible grammar tasks (Ellis, 1997). Therefore, giving grammar awareness lessons in a more structured way is recommended, and it needs teachers' creativity to present such form-focus activities. An example of teaching grammar creatively is using three-phase techniques: Discovery, Consolidation, and Use (Gerngross, Puchta, \& Thornbury, 2010:7). This is different from traditional grammar teaching that employs deductive learning, as it more inductive since it starts with Discovery where learners are exposed with language use to learn, and then Consolidation in which learners understand the tasks containing new grammatical structure, and finally Use that requires learners from learning into practice of using the grammar for communicative purposes.

To accommodate two possible ways to learn L2 rule system, by acquisition and leaning process, teachers would be required to choose suitable strategies, materials, and tasks for their students. For acquisition of L2 rule system to happen, exposure to many sources of reading materials containing the necessary grammar is essential to accommodate the role of input and interaction to promote acquisition. Mitchell and Myles (2014) highlight the importance of making use of SLA research findings in classroom practices. They recommend that teachers identify the L2 language items that might most effectively be taught in sequences that imitate empirically the developmental sequences of L2 acquisition. In addition, to enhance learners pace in acquiring L2 rule system, developing selfdirected learning is crucial. It can be done by providing them with authentic materials in independent learning activities. This has been practiced in the teaching of Complex English Grammar, among others is in the form of assigning learners to find samples of complex sentences. Such consciousawareness raising tasks were effective in helping learners acquire/learn more complex sentences (Mukminatien, 2010). Previously, a possible and more structured way is by providing grammar-based writing assignments (Cahyono \& Mukminatien, 2002). It was effective in improving students' grammatical competence in writing by learning a text containing the targeted grammar items combined with grammar-based writing tasks.

Concerning this research, prior to the discussion of complex sentences, it is necessary to start with the definition of sentences. A sentence refers to a group of words containing a noun phrase (NP), as the subject, and a verb phrase (VP) as the predicate. It is meant to refer to "a string of words which starts with a word beginning with a capital letter and which ends with a word immediately followed by a full stop" (Radford, 1997:271). It can also refer to a group of words containing a subject and a verb plus an object and other information. Concerning sentence types, English sentences can be classified into simple, compound, complex, and compound-complex sentences (Azar, 1999; Rubin, 1983). A simple sentence contains one independent clause, (NP+VP). For example, Maria practices classical piano music every day can be analyzed into Maria as a subject (NP) and practices classical piano music every day as the predicate (VP containing V and another NP + other information), practices as a verb, and classical piano music (as an object or verb compliment, and every day is adverb. A complex sentence is a sentence containing at least one independent clause (a group of words that can stand alone as a simple sentence) and one dependent clause. For example, Maria practices classical piano music everyday because she likes it very much. Maria practices classical piano music every day is the independent clause, while because she likes it very much is the dependent clause. The word because in that sentence is called a subordinate conjunction (Azar, 1999; Rubin, 1983). When the dependent clause begins a sentence, it may begin with other subordinator such as after, before, as soon as, when, if, although, and since. A compound sentence is a sentence containing two or more independent clauses. For example, We went fishing, and then we had lunch. Both we went fishing and we had lunch are independent clauses as each of them can stand alone as a sentence and there is no 
cause-effect relationship. A compound-complex sentence is a sentence containing two or more independent clauses and one or more dependent clauses. For instance, The good news was announced, and as the teacher left, there was a great cheer. The sentence contains one dependent clause and two independent clauses. The good news was announced is an independent clause, as the teacher left is a dependent clause, and there was a great cheer is an independent clause.

There is another syntactical classification used concerning complex sentences: embedded structure and coordinate structure (Folse, Solomon, \& Muchmore-Vokoun, 2009:144). When the dependent clause is embedded in the independent clause like in Maria practices classical piano music that she likes very much every day, it is called embedded structure. In this sentence, that she likes very much is an adjective clause since it modifies the word music. In addition to adjective clause, noun clause and adverbial clause can also be used in the embedded structure of a complex sentence. The second is called coordinate structure as in the previous example. Maria practices classical piano music everyday because she likes it very much. The second clause is the reason for Maria to practice classical piano music every day; so, the two clauses are combined using because. Since the second clause is the sub clause in the complex sentence, the word because is called subordinate conjunction. This research is an analysis and interpretation of the data based on the aforementioned concept or the understanding of these complex sentences.

The theoretical framework underlying this research deals with writing competence, grammatical competence, and SLA theories. The SLA theories would be responsible for explaining learners' grammatical/language development. Referring to language acquisition theories, the ability to produce complex sentences has been done both in L1 and L2 learining. It is an indication of more advanced acquisition of language either the first language (L1) or the second language (L2). The acquisition of complex sentences has been studied a lot in the L1 acquisition. Bowerman (1979), for example, reported a review on research on the children development of complex sentences in spontaneous speech, strategies for parsing complex sentences, and relative clauses. She suggested that analysis of the emergence of a broad range of structures is important. In addition, it is also interesting to examine the interpretive strategies in the acquisition of complex sentence structures. One step that has been conducted is to find out the relationship between comprehension and production of complex sentence structures. Thus, it is evident that acquisition of complex sentences is a crucial part of the children development of their L1. Another study of the acquisition of complex sentences was conducted by van Valin (2001) who examined the importance of the acquisition of complex sentences in L1 by using samples of complex sentences from 7 different languages: English, Hebrew, Kaluli (Papuan language), Korean, Mandarin, Italian, and Polish. The study revealed that a complex sentence construction among children is related to their cognitive development and their language mechanism. An interesting finding of van Valin (2001) was that the used of complex sentences indicating the importance of the communicative function of language.

Research studies reporting the ability in using complex sentences among EFL Indonesian students, however, are still small in number. An example of an investigation of Indonesian students' ability in using complex sentences was done by Mukminatien (1997), as one of her research questions. A cross sectional study was conducted in the English Department of IKIP MALANG (Institute of Teacher Training and Education) in four levels of Writing Course (Writing I, Writing II, Writing III, and Writing IV). The finding showed that the higher the course level, the more complex sentences students produce in their essays. Some other studies are focused on EFL learners' types of error. For example, a study conducted by Tan (n.d.) reported that EFL students' errors include word choice, verb form, missing subject, and verb tense. The study also proposes instructional strategies to cope with the students' problem in the four types of errors. It brings to the conclusion that EFL students need to be taught to use basic elements essential to English writing, more particularly in using verb form/verb tense. Hagiwara (2011) reported a study on the second language learners' production of complex sentences in English on the basis of the listening strategies. This study, which involved Japanese learners, showed that the students' construction of complex sentences contain interference from their L1. However, when the students were given picture-based information through listening, they could produce complex sentences more accurately. This means that the students would be helped more effectively when they could understand the meaning in the listening passages with the help of pictures.

One exceptional study was conducted by Tsang and Wong (2000) who examined the effect of explicit teaching of grammar on the students' ability in writing in terms of writing length, syntactic maturity 
and accuracy of expressions. The students were involved in writing activities containing writing practices with grammar input on the basis of materials from a grammar book. The practices in writing were intended to improve the students' awareness in sentence construction and idea development. The result showed that after 14 weeks of workshop sessions the students were found to extend their writing length and they wrote with more matured syntax in terms of longer and more accurate units and more complex sentences. Thus, Tsang and Wong's (2000) findings suggest that the students' proficiency in writing especially in using language affects their ability in using complex sentences.

In line with Tsang and Wong (2000), this study attempts to add empirical evidence on EFL students' ability in using more complex sentences. This study is very important to provide empirical evidence on the role of complex sentences in expressing meaning (the production) after comprehension (understanding) of complex sentence structures. Unlike Tan's (n.d.) study, this study seeks to investigate how complex sentences contribute to the students' length of essay. This study is also different from Hagiwara's (2011) study which shows the effects of listening to models of complex sentences in listening materials on writing accurate complex sentences, because it focuses on EFL students' writing proficiency, especially opinion essay and their ability in using complex sentences. While Mukminatien's (1997) study identified the EFL learners' development in the ability of writing complex sentences across course levels, this study aimed to examine (1) the students' proficiency in writing, (2) the students' ability in using complex sentences, (3) the relation between the number of sentences in the essays and the number of complex sentences, and (4) the relationship between students' proficiency in writing and the number of complex sentences. The results would be useful for EFL teachers as input for planning their lessons to help learners write a qualified essay, especially writing complex sentences in their writing. It would help them choose suitable materials and strategies for the sake of enhancing learners' grammatical competence in writing.

\section{METHOD}

This study involved 54 students who took Argumentative Writing course in the English Department curriculum of Universitas Negeri Malang, one of well-known universities in Indonesia, having a reputable ELT Study Program. Argumentative Writing, in the current curriculum, is the most advanced writing course offered in the department after Paragraph Writing and Essay Writing courses. Therefore, in this course level, the students are assumed to have mastered the knowledge and skills of writing a good paragraph and essays of five types of development: exemplification, comparison/contrast, classification, process analysis, and cause-and-effect analysis. In the Argumentative Writing course, the students were trained to write two types of argumentative essays. The first is opinion essay in which the students express reasons from one side, namely their own opinion. The second one is argumentative essay in which the students express their own opinion and at the same time consider other people's opinion as the points for refutation to defend their arguments. The students were divided into two classes, class A (28 students) and class B (26 students). Each of the two classes consisted of both male and female students.

The materials used in argumentative writing course is based on Oshima and Hogue $(2006 ; 2007)$ and Smalley et al., (2001). For the purpose of this study, the students were asked to write an essay with a topic of general interest. The topics were selected from the list in the materials written by Smalley et al. (2001) which included four topics: (1) Arranged marriage; (2) Censorship of books, songs, and movies; (3) Laws against cell phone use while driving, and (4) Prohibition of smoking in public places. The distribution of students who chose to write on each topic is shown in Table 1.

Table1. Distribution of Topics Written by the Students

\begin{tabular}{|l|l|l|l|}
\hline No & Topic & \multicolumn{2}{|l|}{ Frequency (N=54) } \\
\cline { 3 - 4 } & & Class A & Class B \\
\hline 1 & Arranged marriage & 9 & 7 \\
\hline 2 & Censorship of books, songs, and movies & 10 & 7 \\
\hline 3 & Laws against cell phone use while driving & 4 & 6 \\
\hline 4 & Prohibition of smoking in public places & 5 & 6 \\
\hline & Total & $\mathbf{2 8}$ & $\mathbf{2 6}$ \\
\hline
\end{tabular}

The opinion essays of the students were analyzed by using the following procedures. First, the students' essays were assessed by using ESL Composition Profile by Hartfiel et al. (1985), employing 
1-100 score range, in order to measure their proficiency in writing. The assessments of students' writing were conducted by two raters who were involved in the data analysis. The two raters discussed points of agreement in scoring on the basis of the ESL Composition Profile. When disagreement took place, resulting in extremely different scores (more than 10), the raters discussed the reasons behind the score difference. This was conducted to achieve a close agreement on making judgment resulted in scores. The results of the students' scores from the two classes are shown in Appendix 1.

Second, the total number of sentences students wrote was tallied. The number of complex sentences was then counted out of the total number of the sentences in the essay. In examining the students' complex sentences, two kinds of structures have been used, namely coordinating structure (using subordinate conjunction) and embedded structure (in the form of an embedded clause). Each of these syntactic structures has different patterns. However, in the analysis, the two types of syntactic structures were not compared. They were counted as complex sentences. Thus, the total number of sentences needs to be known in order to find the proportion in the use of complex sentences compared to the total number of sentences in the students' essays. The higher proportion of the complex sentences is considered to indicate that the students use more complex sentences than other types of sentences (simple and compound sentences). The result of the analysis of students' proportion in the use of complex sentences is shown in Appendix 2.

Third, the total number of the sentences was correlated to the number of complex sentences in order to know whether complex sentences have significant role in the composition of essay.

Fourth, the students' proficiency in writing was correlated with the number of complex sentences the students have written. For this purpose, we consider that the higher the level of the students' proficiency in writing, the more frequent they used complex sentences in their essays. This idea is relevant to the opinion of Bowerman (1979) who stated that the ability in using complex sentences among children who are in the process of acquiring L1 indicates their improvement in the mastery of the use of more complex syntactic structures. To do so, the scores of the proficiency in writing of the students from two classes were ranked along with the number of the complex sentences. Pearson product moment correlation was used to identify the correlation coefficient between the students' proficiency in writing and their ability in using complex sentences. The list of the students' ranked scores of proficiency in writing and the number of the complex sentences is shown in Appendix 3. Based on the table of levels of competence established by Universitas Negeri Malang, the table of competence category is shown in Table 2. Based on Table 2, the scores of proficiency in writing and language use were classified into some categories: advanced, pre-advanced, intermediate, preintermediate and beginner.

Table2. Levels of Competence in Overall Proficiency in Writing Using Hartfiel et al.,'s ESL Composition Profile

\begin{tabular}{|l|l|l|}
\hline No. & Levels of Competence & Overall Proficiency in Writing (maximum score = 100) \\
\hline 1 & Advanced & $85-100$ \\
\hline 2 & Pre-advanced & $80-84$ \\
\hline 3 & Intermediate & $75-79$ \\
\hline 4 & Pre-intermediate & $70-74$ \\
\hline 5 & Beginner & $65-69$ \\
\hline
\end{tabular}

\section{FINDINGS}

The first research question deals with the students' proficiency in writing. The results of the analysis of the students' proficiency in writing showed that the highest score was 89 out of the possible maximum score 100, while the lowest score was 70 (see Appendix 1). Further computation showed that the mean score of the 54 students from the two classes was 78.24, indicating that the students' proficiency in writing is at the intermediate level.

The second research question addresses the students' ability in using complex sentences. The total number of the sentences that the 54 students wrote was 1782 with the average of 33 , while the total number of the complex sentences was 1004 with the average of 18.59. Thus, the average proportion of the total number of the complex sentences was 56.41. This shows that the students used more complex sentences than other types of sentences in their essays (see Appendix 2).

Prior to the analysis of the correlation between the number of sentences and the number of complex sentences (see Appendix 3), Kolmogorov-Smirnov test was conducted to examine the fulfillment of 
normality assumption of the data used in this study. This test examined whether the data from the number of sentences and the number of complex sentences were distributed normally. The result of Kolmogorov-Smirnov test performed by using SPSS 18 program is shown in Table 3.

Table3. The Result of Kolmogorov-Smirnov Test on the Number of Sentences and the Number of Complex Sentences

\begin{tabular}{|l|l|l|l|}
\hline \multicolumn{2}{|c|}{} & Number of Sentences & Number of Complex Sentences \\
\hline $\mathrm{N}$ & Mean & 54 & 54 \\
\hline \multirow{2}{*}{ Normal Parameters } & a,b & 33.0000 & 18.5926 \\
\cline { 2 - 4 } & Std. Deviation & 5.24854 & 5.20710 \\
\hline \multirow{3}{*}{ Most Extreme Differences } & Absolute & .112 & .104 \\
\cline { 2 - 4 } & Positive & .059 & .100 \\
\cline { 2 - 4 } & Negative & -.112 & -.104 \\
\hline Kolmogorov-Smirnov Z & .822 & .767 \\
\hline Asymp. Sig. (2-tailed) & .509 & .599 \\
\hline
\end{tabular}

a. Test distribution is Normal. b. Calculated from data.

The result of Kolmogorov-Smirnov test showed that the $p$ values for the number of sentences and the number of complex sentences, were greater than .05 level of significance ( $p$ value $_{1} .509>.05 ; p$ value $_{2}$ $.599>.05)$. This means that the number of sentences and the number of complex sentences written by the students were distributed normally. Given that the data used in this study already fulfilled the normality assumption, Pearson product moment correlation in SPSS 18 program was performed to analyze the correlation between the number of sentences and the number of complex sentences. The detailed result is shown in Table 4.

Table4. The Correlation Analysis between the Number of Sentences and the Number of Complex Sentences

\begin{tabular}{|l|l|l|l|}
\hline \multicolumn{2}{|c|}{} & Number of Sentences & Number of Complex Sentences \\
\hline \multirow{4}{*}{ Number of Sentences } & Pearson Correlation & 1 & $.510^{* *}$ \\
\cline { 2 - 4 } & Sig. (1-tailed) & & .000 \\
\cline { 2 - 4 } & $\mathrm{N}$ & 54 & 54 \\
\hline \multirow{2}{*}{$\begin{array}{l}\text { Number of Complex } \\
\text { Sentences }\end{array}$} & Pearson Correlation & $.510^{* *}$ & 1 \\
\cline { 2 - 4 } & Sig. (1-tailed) & .000 & 54 \\
\cline { 2 - 4 } & $\mathrm{N}$ & 54 & 54 \\
\hline
\end{tabular}

**. Correlation is significant at the 0.01 level (1-tailed).

The result showed that the $p$ value of the correlation was .000 , which was lower than .05 level of significance $(p$ value < .05). It was concluded that the number of sentences and the number of complex sentences were significantly correlated. The correlation coefficient obtained from the analysis was then interpreted based on the criteria of correlation level by Salkind (2000): correlation coefficient .8 to 1.0 classified as very strong correlation, .6 to .8 as strong correlation, .4 to .6 as moderate correlation, .2 to .4 as weak correlation, and .0 to .2 classified as no or very weak correlation. Thus, the coefficient correlation of .510 from the analysis indicates the moderate correlation between the number of sentences and the number of complex sentences. It can be stated that if the number of sentences the students have written is high, the number of complex sentences is likely to be high.

The subsequent analysis was conducted to examine whether or not the students' proficiency in writing was correlated with the number of complex sentences they produced. Similarly, Kolmogorov-Smirnov test was done to examine whether the students' proficiency scores in writing had normal distribution. The result of the analysis is shown in Table 5.

Table5. The Result of Kolmogorov-Smirnov Test on the Students' Proficiency in Writing and the Number of Complex Sentences

\begin{tabular}{|l|l|l|l|}
\hline \multicolumn{2}{|l|}{} & Proficiency in Writing & Number of Complex Sentences \\
\hline $\mathrm{N}$ & Mean & 54 & 54 \\
\hline \multirow{2}{*}{ Normal Parameters } & a,b & 78.2407 & 18.5926 \\
\cline { 2 - 4 } & Std. Deviation & 3.66490 & 5.20710 \\
\hline \multirow{3}{*}{ Most Extreme Differences } & Absolute & .101 & .104 \\
\cline { 2 - 4 } & Positive & .093 & .100 \\
\cline { 2 - 4 } & Negative & -.101 & -.104 \\
\hline Kolmogorov-Smirnov Z & .739 & .767 \\
\hline Asymp. Sig. (2-tailed) & .646 & .599 \\
\hline
\end{tabular}

a. Test distribution is Normal, $b$. Calculated from data. 
The result of the second Kolmogorov-Smirnov test showed that the students' proficiency scores in writing had normal distribution as indicated by $p$ value of .646 which was greater than .05 level of significance ( $p$ value $>.05$ ). Subsequently, the same statistical analysis, Pearson product moment correlation, was conducted to examine the correlation between the students' proficiency in writing and the number of complex sentences they produced as shown in Table 6.

Table6. The Correlation Analysis between the Students' Proficiency in Writing and the Number of Complex Sentences

\begin{tabular}{|l|l|l|l|}
\hline \multicolumn{2}{|l|}{} & Proficiency in Writing & Number of Complex Sentences \\
\hline Proficiency in Writing & Pearson Correlation & 1 & $.315^{*}$ \\
\cline { 2 - 4 } & Sig. (1-tailed) & & .010 \\
\cline { 2 - 4 } & $\mathrm{N}$ & 54 & 54 \\
\hline \multirow{2}{*}{$\begin{array}{l}\text { Number of Complex } \\
\text { Sentences }\end{array}$} & Pearson Correlation & $.315^{*}$ & 1 \\
\cline { 2 - 4 } & Sig. (1-tailed) & .010 & \\
\cline { 2 - 4 } & $\mathrm{N}$ & 54 & 54 \\
\hline
\end{tabular}

*. Correlation is significant at the 0.05 level (1-tailed).

The correlation analysis as shown in Table 6 yielded $p$ value of .010 , which was lower than .05 level of significance ( $p$ value <.05). Accordingly, the correlation analysis demonstrated a similar result as the previous analysis in which there was correlation between the students' proficiency in writing and the number of complex sentences the students have written. Based on the correlation level by Salkind (2000), the correlation coefficient of .315 from the analysis was interpreted that the correlation between the students' proficiency in writing and the number of complex sentences was in the weak level.

\section{DISCUSSION}

The results of the study show that the five components of writing (Hartfiel et al., 1985) are important aspects of writing that should be taken into consideration. Language use aspect, as mentioned earlier, constituted to $25 \%$ weighting of the writing assessment. This suggests that language use is important in making up the students' proficiency in writing. Looking at the results of this study, the proficiency in writing of the students is still in the intermediate level. Therefore, there is a possibility to increase the level of the students' proficiency in writing into higher level, pre-advanced or advanced level by working on the aspect of language use, especially more construction of complex sentences.

This is especially the case when we look into the result of the second research question, which shows that the number of complex sentences were more than half of the number of the other types of sentences. As Bowerman (1979) and van Valin (2001) argue, the development of complex sentences as part of elements of communication indicates the more mature of their grammatical in their L1. Similary, we argue that the development in the use of complex sentences in the students' essays indicates that the students have achieved more advanced level of their grammatical competence in their writing proficiency. This is understandable that the students involved in this study were in the fourth semester in their four-year undergraduate education.

The results of the study also reveal that the number of complex sentences is moderately correlated with the number of sentences in the students' essays. It is important to note that the essays written by the students commonly consist of five paragraphs as shown in the majority of the examples provided in the textbook used in the Argumentative Writing course (Oshima \& Hogue, 2006, 2007; Smalley et al., 2001). In case that students have problems in developing their sentences for each of the paragraphs, understanding the use of complex sentences might help them in constructing sentences for their essays. In writing an opinion essay, the students are required to be able to use discourse markers to clarify the use of reasons in their opinion essays, especially the inferential markers (Fraser, 1999) such as the use of because, since, then, hence, and as.

The finding of the study further shows that the students' proficiency in writing, more particularly in developing ideas in the form of sentences in their essays, is related to the number of complex sentences. This is in line with the finding of the research conducted by Tsang and Wong (2000) who considered that syntactic development has an important role in extending the students' writing products as shown by more use of complex sentences. This implies that in teaching writing, developing students' ability to use complex sentences cannot be taken for granted. This means that regardless of the approaches in the teaching of writing, either holistic or analytical writing, in some 
way there should be a time spent to focus on forms (dealing with the construction of complex sentences in sufficient time) and more examples of complex sentences need to be shown and learned by including the embedded and the coordinating types of complex sentences).

The finding of the correlation between the students' proficiency in writing and the number of complex sentences suggests that teachers cannot depend solely on the number of complex sentences to have students extend the number of sentences in their essays. Other possible ways to help the students extend the number of sentences in their essays are developing the supporting sentences for the topic sentences more sufficiently and then encouraging the students to use transition markers to show the relationships between sentences. Thus, the results of this study reveal that complex sentences have prominent role in building the students' competence in writing essays which eventually indicates their writing proficiency.

\section{Conclusion}

This study has revealed that complex sentences have an important role in contributing the quality of EFL students' essays. Although the EFL students have used various types of sentences in their essays, the use of complex sentences was apparently more dominant than the other types of sentences. This indicates that the students have developed their writing ability in their stage of taking Argumentative Wrting as the most advanced in the series of three writing courses. With the moderate correlation between the number of sentences and the number of complex sentences in the students' essays, the component of language use needs to be given more attention as it contributes to the one-fourth of the achievement in writing. Therefore, teachers of EFL writing are recommended to remind the students of the function of the structure of coordinating and embedded statements in constructing complex sentences. The attempt to raise the students' awareness of the importance of complex sentences can be done through explicit teaching (for the whole students in the class) or through teacher feedback individually (for those who have problems in constructing the grammatical patterns). Along with the proper use of other components (content, organization, vocabulary, and mechanism), the accurate use of complex sentences will contribute to their remarkable development in writing proficency, which is the ultimate goal of the teaching of EFL writing.

\section{REFERENCES}

[1] Azar, B. S. 1999. Understanding and using English grammar. New York: Pearson Education.

[2] Bowerman, M. (1979). The acquisition of complex sentences. In M. Garman, \& P. Fletcher (Eds.), Studies in language acquisition (pp. 285-305). Cambridge: Cambridge University Press.

[3] Cahyono, B.Y., \& Mukminatien, N. (2002). Meminimalkan kesalahan gramatika di kelas writing melalui structure-based writing assignments [Minimizing students' errors in a writing class through structure-based writing assignment. Jurnal Ilmu Pendidikan, 2(9), 131-141.

[4] Canale, M., \& Swain, M. (1980). Approaches to communicatiev competence. Singapore: SEAMEO Regional Language Competence.

[5] Dulay, H., Burt, M., \& Krashen, S, D. (1982). Language two. Oxford: Oxford University Press.

[6] Ellis, R. 1997. SLA Research and Language Teaching. Oxford: Oxford University Press.

[7] Folse, K.S., Solomon, E.V., \& Muchmore-Vokoun, A. (2009). Great sentences for great paragraphs. Singapore: Cengage Learning Asia.

[8] Fraser, B. (1999). What are discourse markers?. Journal of Pragmatics, 31, 931 - 952.

[9] Gerngross, G., Puchta, H., \& Thornbury, S. (2013). Teaching grammar creatively. Retrieved from www.helblinglanguages.com

[10] Hagiwara, A. (2010). Attention and L2 learners' segmentation of complex sentences. [Unpublished $\mathrm{PhD}$ thesis]. The University of Iowa, Iowa city, Iowa.

[11] Hartfiel, V. F., Jacobs, H. L., Zinkgraft, S.A., Wormuth, D. R., \& Hughey, J. B. (1985). Learning ESL composition. Rowley, MA: Newbury House.

[12] Jacobs, H. L., Zinkgraft, S.A., Wormuth, D. R., Hartfiel, V. F., \& Hughey, J. B. (1981). Testing ESL composition: A practical approach. Rowley, MA: Newbury House.

[13] Krashen, S.D. (1981). Second language acquisition. Cambridge: Cambridge University Press.

[14] Krashen, S.D. (1985). The input hypothesis: Issues and implications. London: Longman. 
[15] Krashen, S.D., \& Terrle, T.D. (1983). The natural approach: Language acquisition in the classroom. Oxford: Pergamon Press.

[16] Mitchell, R., \& Myles, F. (2013). Second language learning theories. London: Rotledge.

[17] Mukminatien, N. (1997). The differences of students' writing achievements across different course levels. [Unpublished Dissertation]. IKIP Malang, Malang.

[18] Mukminatien, N. (2010). Menumbuhkan self-directed learning dengan memanfaatkan TIK dalam pembelajaran complex English grammar [Promoting self-directed learning by utilizing information and communication technology in the teaching of complex English grammar]. [Unpublished Research Report]. Malang: Universitas Negeri Malang.

[19] Oshima, A., \& Hogue, A. (2006). Writing academic English. White Plains, NY: Pearson.

[20] Oshima, A., \& Hogue, A. (2007). Introduction to academic writing. New York: Pearson Education.

[21] Radford, A. (1997). Syntax: A minimalist introduction. Cambridge: Cambridge University Press.

[22] Salkind, N.J. (2000). Statistics for people who (they think) hate Statistics. Thousand Oaks, CA: Sage Publications, Inc.

[23] Savignon, S. J. 1983. Communicative competence; Theory and classroom practice: Texts and contexts in language classroom. Reading: Addison: Addison Westley Publishing Company.

[24] Smalley, R. L., Ruetten, M. K., \& Kozyrev, J. R. (2001). Refining composition skills: Rhetoric and grammar for ESL students. Boston, MA: Heinle \& Heinle.

[25] Tan, H-M. (n.d.). A study of EFL learners' writing errors and instructional strategies. Retrieved April 8, 2013, from http://ir.lib.ksu.edu.tw/bitstream/

[26] Tsang, W.K., \& Wong, M. (2000). Giving grammar the place it deserves in process writing. Prospect, 15, 34-45.

[27] Van Valin, R. C. (2001). The acquisition of complex sentences: A case study in the role of theory in the study of language development. Retrieved May 27, 2016 from https://www.acsu. buffalo.edu/ vanvalin/rrg/vanvalin_papers/Acq_of_complex_sent.pdf

[28] Zemach, D. E. \& Rumisek, L.A. 2005. Academic writing: From paragraph to essay. Oxford: Macmillan Education.

\section{APPENDIX}

Appendix 1

List of the students' scores of proficiency in writing

\begin{tabular}{|l|l|l|l|l|}
\hline \multirow{2}{*}{ No } & Class A & Class B & Score \\
\cline { 2 - 5 } & Name & 78 & Name & 80 \\
\hline 1 & APP & AF & ARF & 82 \\
\hline 2 & AF & 79 & ATP & 89 \\
\hline 3 & AB & 82 & AYP & 83 \\
\hline 4 & AL & 76 & AN & 79 \\
\hline 5 & AS & 71 & DAF & 77 \\
\hline 6 & ANR & 79 & DK & 83 \\
\hline 7 & ACA & 70 & DDW & 84 \\
\hline 8 & BDS & 83 & EJDP & 77 \\
\hline 9 & CP & 79 & FNE & 78 \\
\hline 10 & DNA & 75 & FH & 78 \\
\hline 11 & EFR & 75 & FKI & 76 \\
\hline 12 & FF & 79 & HAAV & 77 \\
\hline 13 & HCS & 75 & IS & 81 \\
\hline 14 & HAI & 74 & IR & 84 \\
\hline 15 & IIR & 73 & MGF & 80 \\
\hline 16 & JH & 77 & RT & 79 \\
\hline 17 & JT & 81 & RAD & 77 \\
\hline 18 & LRH & & & \\
\hline
\end{tabular}


Bambang Yudi Cahyono et al.

\begin{tabular}{|c|c|c|c|c|}
\hline 19 & MAA & 80 & RD & 79 \\
\hline 20 & NS & 80 & RFH & 80 \\
\hline 21 & NGP & 76 & RGSN & 80 \\
\hline 22 & NS & 76 & SSN & 84 \\
\hline 23 & PK & 75 & SA & 79 \\
\hline 24 & RAR & 75 & TIY & 80 \\
\hline 25 & TA & 74 & UVW & 77 \\
\hline 26 & VS & 76 & ZK & 79 \\
\hline 27 & YY & 81 & & \\
\hline 28 & YA & 71 & & \\
\hline \multicolumn{2}{|c|}{ Mean } & 76.54 & Mean & 80.08 \\
\hline
\end{tabular}

Appendix 2

List of the total number of sentences in the students' essays and the proportion of the use of complex sentences

\begin{tabular}{|c|c|c|c|c|c|c|c|c|}
\hline \multirow{2}{*}{ No } & \multicolumn{4}{|c|}{ Class A } & \multicolumn{4}{|c|}{ Class B } \\
\hline & Name & $\mathrm{S}$ & CS & $\%$ & Name & $\mathrm{S}$ & CS & $\%$ \\
\hline 1 & APP & 32 & 20 & 62.5 & ARF & 33 & 19 & 57.58 \\
\hline 2 & $\mathrm{AF}$ & 29 & 18 & 62.07 & ATP & 32 & 25 & 78.13 \\
\hline 3 & $\mathrm{AB}$ & 40 & 21 & 52.5 & AYP & 37 & 24 & 64.86 \\
\hline 4 & $\mathrm{AL}$ & 38 & 16 & 42.11 & AN & 30 & 21 & 70.00 \\
\hline 5 & AS & 30 & 13 & 43.33 & DAF & 37 & 15 & 40.54 \\
\hline 6 & ANR & 35 & 20 & 57.14 & $\mathrm{DZ}$ & 29 & 22 & 75.86 \\
\hline 7 & ACA & 24 & 14 & 58.33 & DK & 36 & 26 & 72.22 \\
\hline 8 & BDS & 15 & 5 & 33.33 & DDW & 30 & 17 & 56.67 \\
\hline 9 & $\mathrm{CP}$ & 37 & 23 & 62.16 & EJDP & 32 & 27 & 84.38 \\
\hline 10 & DNA & 36 & 33 & 91.67 & FNE & 33 & 16 & 48.48 \\
\hline 11 & EFR & 25 & 13 & 52 & FH & 30 & 16 & 53.33 \\
\hline 12 & FF & 31 & 17 & 54.84 & FKI & 31 & 14 & 45.16 \\
\hline 13 & HCS & 33 & 18 & 54.55 & HAAV & 33 & 19 & 57.58 \\
\hline 14 & HAI & 26 & 17 & 65.38 & IS & 35 & 14 & 40.00 \\
\hline 15 & IIR & 39 & 21 & 53.85 & IR & 36 & 21 & 58.33 \\
\hline 16 & $\mathrm{JH}$ & 36 & 20 & 55.56 & MGF & 26 & 21 & 80.77 \\
\hline 17 & JT & 31 & 16 & 51.61 & RT & 34 & 18 & 52.94 \\
\hline 18 & LRH & 43 & 30 & 69.77 & RAD & 31 & 13 & 41.94 \\
\hline 19 & MAA & 32 & 21 & 65.63 & RD & 38 & 24 & 63.16 \\
\hline 20 & NS & 39 & 28 & 71.79 & RFH & 37 & 15 & 40.54 \\
\hline 21 & NGP & 29 & 14 & 48.28 & RGSN & 38 & 13 & 34.21 \\
\hline 22 & NS & 29 & 20 & 68.97 & SSN & 37 & 16 & 43.24 \\
\hline 23 & PK & 33 & 13 & 39.39 & SA & 33 & 21 & 63.64 \\
\hline 24 & RAR & 32 & 17 & 53.13 & TIY & 34 & 10 & 29.41 \\
\hline 25 & TA & 44 & 20 & 45.45 & UVW & 34 & 23 & 67.65 \\
\hline 26 & VS & 40 & 25 & 62.5 & ZK & 36 & 14 & 38.89 \\
\hline 27 & YY & 32 & 14 & 43.75 & & & & \\
\hline 28 & YA & 20 & 13 & 65 & & & & \\
\hline \multicolumn{2}{|c|}{ Mean } & 32.5 & 18.57 & 56.66 & Mean & 33.54 & 18.62 & 56.14 \\
\hline
\end{tabular}

Note: $\mathrm{S}$ is number of sentences; CS is number of complex sentences; $\%$ is the proportion of the complex sentences and the number of sentences.

Appendix 3

The rank of the students' scores of proficiency in writing and the number of complex sentences the students wrote

\begin{tabular}{|l|l|l|l|l|l|l|l|}
\hline No. & Students & PiW & NCS & No. & Students & PiW & NCS \\
\hline 1 & AYP & 89 & 24 & 28 & ZK & 79 & 14 \\
\hline 2 & DDW & 84 & 17 & 29 & APP & 78 & 20 \\
\hline 3 & IR & 84 & 21 & 30 & FNE & 78 & 16 \\
\hline 4 & SSN & 84 & 16 & 31 & FH & 78 & 16 \\
\hline 5 & CP & 83 & 23 & 32 & JT & 77 & 16 \\
\hline
\end{tabular}


Indonesian Students' Writing Proficiency and Their Ability in Using Complex Sentences

\begin{tabular}{|l|l|l|l|l|l|l|l|}
\hline \hline 6 & AN & 83 & 21 & 33 & DZ & 77 & 22 \\
\hline 7 & DK & 83 & 26 & 34 & EJDP & 77 & 27 \\
\hline 8 & AL & 82 & 16 & 35 & HAAV & 77 & 19 \\
\hline 9 & ATP & 82 & 25 & 36 & RAD & 77 & 13 \\
\hline 10 & LRH & 81 & 30 & 37 & UVW & 77 & 23 \\
\hline 11 & YY & 81 & 14 & 38 & AS & 76 & 13 \\
\hline 12 & IS & 81 & 14 & 39 & NGP & 76 & 14 \\
\hline 13 & MAA & 80 & 21 & 40 & NS & 76 & 20 \\
\hline 14 & NS & 80 & 28 & 41 & VS & 76 & 25 \\
\hline 15 & ARF & 80 & 19 & 42 & FKI & 76 & 14 \\
\hline 16 & MGF & 80 & 21 & 43 & EFR & 75 & 13 \\
\hline 17 & RFH & 80 & 15 & 44 & FF & 75 & 17 \\
\hline 18 & RGSN & 80 & 13 & 45 & HAI & 75 & 17 \\
\hline 19 & TIY & 80 & 10 & 46 & PK & 75 & 13 \\
\hline 20 & AB & 79 & 21 & 47 & RAR & 75 & 17 \\
\hline 21 & ACA & 79 & 14 & 48 & IIR & 74 & 21 \\
\hline 22 & DNA & 79 & 33 & 49 & TA & 74 & 20 \\
\hline 23 & HCS & 79 & 18 & 50 & AF & 73 & 18 \\
\hline 24 & DAF & 79 & 15 & 51 & JH & 73 & 20 \\
\hline 25 & RT & 79 & 18 & 52 & ANR & 71 & 20 \\
\hline 26 & RD & 79 & 24 & 53 & YA & 71 & 13 \\
\hline 27 & SA & 79 & 21 & 54 & BDS & 70 & 5 \\
\hline Mean & & & & & 78.24 & 18.59 \\
\hline
\end{tabular}

\section{AUTHORS' BIOGRAPHY}

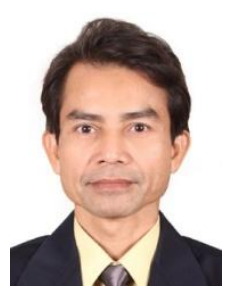

Bambang Yudi Cahyono, is a Professor in Applied Linguistics at Universitas Negeri Malang, East Java, Indonesia. He earned his MA degree from Concordia University, Montreal, Canada and PhD from the University of Melbourne, Australia.

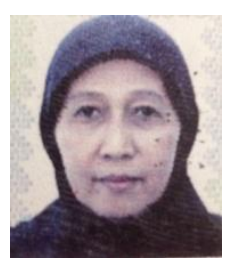

Nur Mukminatien, is a Professor in Teaching English as a Foreign Language (TEFL) at Universitas Negeri Malang. She earned her undergraduate (1985), master (1991) and doctorate (1997) degrees which are in English Language Teaching (ELT) from the same university. She had experiences in teaching English in primary and secondary schools in Moscow and in presenting papers in national and international conferences.

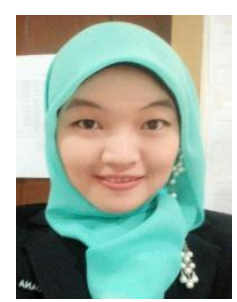

Rosyi Amrina, is now teaching English at Universitas Lambung Mangkurat, South Kalimantan, Indonesia. She obtained her Bachelor degree in English Language Teaching from Universitas Lambung Mangkurat, South Kalimantan and MA degree from Universitas Negeri Malang. 